\title{
Using Moodle in University Courses and Its Impact on Future Anxiety and Psychological Happiness
}

\author{
Raed Al-kreimeen and Odeh Murad \\ Al Balqa Applied University- Faculty of Al Shoubak University College- Jordan \\ odehmurad@bau.edu.jo \\ raedalk@bau.edu.jo
}

\begin{abstract}
Following the coronavirus pandemic, this study sought to determine the impact of using Moodle in teaching university courses on students' future anxiety and psychological happiness. The study sample consisted of 75 students (males and females) in the summer semester of the academic year 2019/2020. The study adopted the quasi-experimental approach by a single experimental group. To achieve the purposes of the study, the researchers developed two scales: firstly, the future anxiety scale, and secondly, the psychological happiness scale; after verifying their reliability and validity, both scales were applied before and after the study sample (pre-scale and post-scale). The findings showed that there are statistically significant differences in the level of future anxiety for the study group individuals in both scales pre-scale and post-scale, to the benefit of post-scale. However, the findings explained the existence of statistically significant differences at $\alpha=0.05$ among the levels of psychological happiness for the study group individuals in both scales (pre-scale and post-scale) and in favor of the latter because of the use of electronic learning management systems in teaching university courses. It shows that implementing Moodle technology into teaching had a positive impact in reducing future anxiety and increasing psychological happiness among university students.
\end{abstract}

Keyword: electronic learning management system, Moodle, future anxiety, psychological happiness

\section{Introduction}

The outbreak of the coronavirus (COVID-19) imposed itself on all sectors of the world, and its negative impacts became gradually obvious on the sectors of economy, health and education. Moreover, the crisis has put the world in front of many real and unavoidable yardsticks which called for coexistence with this epidemic according to various circumstances and facts not previously known; all of this led to many losses in these sectors (Zayed, 2020). The individual is currently living in a changing and complicated world, and the pandemic has added a new global horror that has complicated the issue and increased the individual's anxiety about the future. In addition, the individual was unable to achieve his goal, and the goals were unable to provide peace, assurance and psychological security (Murad, 2021). There is, therefore, no precedence for psychological happiness because university students are anxious about the future and its surprises, as well as the extraordinary changes that they are unfamiliar with and which exceed their capacity to adapt to these circumstances as future interest is a major concern for them. (Mo'ayad, 2010).

Concern about the future is an inevitable result of what university students think about in order to organize their lives based on their studies, and thus, anxiety is increasing and being highlighted as an effective power in an individual's life due to the pressure he/she is under in addition to the requirements imposed by the nature of life he/she lives, especially during university youth and the ambitions and hopes it has (Zeidan, 2007).The most important thing that causes anxiety in university students is their thinking about the future and ensuring success in their jobs, as well as self-realization and accomplishment in the construction of social relationships, as this increases their feelings of frustration, self-anxiety, and worry about their future as a result of excess aspirations and expectations, as all of this leads to his failure (Murad, 2020).Yet, in addition to the current complications, the Coronavirus pandemic added greater complications since most countries are unable to predict the future as a result of the rapid spread of the epidemic and the inability to contain it. For that reason, the matters get more complicated and the anxiety sharpness of the future increases for university students who hope to complete their graduation requirements to move to the labor market and achieve their goals (Zayed, 2020). As a result of all of the aforementioned factors, as well as to avoid the detrimental effects of the epidemic on education, students and teachers in universities have chosen to provide each other with free internet packages so that everyone can continue the educational process and ensure that the students' right to continue their education is protected. In 
addition, the principle of success and failure is applied to distance teaching courses. (Ministry of Higher Education and Scientific Research, 2020).

"Fear, or tension or distress arises from the expectation of some threat whose source is mainly unknown or unclear. Both anxiety and fear are accompanied by variables that help to building the sense and feeling of danger," according to the American Society of Psychology (Balkelani, 2008). There are many sources of anxiety, the most important of which is expectation of any threat for the individual whether this threat is obvious or mysterious for the individual. Moreover, the expectation is connected with future events and accompanied to a status of extreme apprehension that is difficult for an individual to deal with, causing stress and disorder in various aspects of behavior (Barlow, 2000).

Many people find it difficult to live with humanity and achieve their ambitions and goals because of the challenges and difficulties they face in society as a whole (Murad, 2020). This is especially true for university students who face enormous difficult obstacles that have a direct impact on their emotional state, success, and ambition. It is confirmed that positive aspects such as happiness and optimism affect the human life positively and provide the individual with more ability to meet the life and its requirements by gaining positive psychological characteristics and features such as psychological happiness and creating ambition for them are important (Miller, et al., 2008).Psychological happiness is regarded as an important sign of the basic indicators to cope with psychological health since happiness is a goal that everyone strives for. However, as the COVID-19 virus spreads, the barriers to achieving happiness are increasing.

\subsection{Reasons of the future anxiety:}

Anxiety in general is linked to a number of factors, as identified by (Eysenck, Susanna and Santos, 2006), including the following:

Tendency and proclivity for anxiety reaction as a personality trait, living experiences on the individual and group levels that are the result of success and failure, an event experienced by an individual in a historical period in addition to social events and political conflicts, and the sudden emergence of dangers such as terrorism, chronic diseases, pandemics, and epidemics

According to Molin (1990), future anxiety can be caused by a number of factors, including the individual's low potential and inability to cope with the problems he faces, the individual's inability to distinguish between his wishes and expectations based on reality, his poor ability to predict the future and his lack of sufficient information to build future thoughts, and contradictions and large gaps between his dreams and motivations. For the reasons stated above, it is demonstrated that there is no single cause of anxiety, so all determinants and their mutual reactions must be considered, in which there are numerous factors interfering with the emergence of anxiety and its persistence, such as factors resulting from knowledge, behavioral, biological, and environmental systems (Spence and Rapee, 2016).

\subsection{Reasons of psychological happiness:}

There are various factors for psychological happiness, according to Al-Jammal (2013), but the most essential ones are: Individual balancing between self-interest and the greater good (interest), and being able to meet basic necessities. The harmony between the individual's concepts of self and the experiences he has had in his life phases and through his treatment of others with what he does, and the individual not suffering from any psychological or mental illness, means keeping the individual balanced and that he has to resolve conflicts.

\subsection{Types of psychological happiness:}

There are several types of psychological happiness which Suleiman (2010) mentioned, including short-term happiness which lasts for a short period of time, similar to receiving a reward or bonus. Long-term happiness is defined as a series of short-term happiness stimuli that are constantly renewed to provide a sense of permanent happiness, such as landing a prestigious job. Real happiness satisfies physical and spiritual needs; instinctive happiness represents moments of pleasure and joy, as well as social and psychological stability, in order to satisfy needs and innate and physical instincts. 


\subsection{E-learning management system:}

The COVID-19 pandemic has forced colleges to use online distance learning as a response. The learning management system (LMS) has evolved into a tool or strategy highly reliant on university education.

Moreover, most universities around the world have used the E-learning management systems, be it open-source systems such as (Moodle, Dokeos) or commercial source like (Blackboard, Atuter). Studies illustrate, as mentioned in Mahmoud (2015), that $90 \%$ of the universities provide their programs via E-learning management systems. These systems enhance the educational process by allowing faculty members to submit educational materials like courses, exams, and sources to the system's website, as well as offering chat rooms, debates, and electronic completion files, among other electronic activities to complement course materials (Zengin, 2012).

Modular Object-Oriented Dynamic Learning Environment Moodle delivers scientific material, tracks learning, and designs exams and educational activities, as well as communication, registration processes, and school schedules. As a result, Moodle is regarded as an integrated system to manage the educational process; it also includes course management, and simultaneous and asynchronous communication. Furthermore, the system includes virtual classrooms, which allow academic staff to communicate with their students while they are in the classroom (Cavus \& Momani, 2009).Looking through previous theoretical literature, the two researchers were unable to find a study that included all of the current study variables, and the studies differed in their objectives. For example, some studies, such as Al-Sabawi (2007), Al-Safasfeh and Mahameed (2007), Mo'ayad (2010), and Al-Momani and Naeem (2013), aimed to reveal the level of future anxiety. The study of Sa'di and Shareebeh (2017) revealed a statistically significant positive correlation between future anxiety, irrational thoughts, and psychological pressures

Nevertheless, findings of Al-Taher (2010) indicated the existence of positive correlation between future anxiety and the psychological pressures sources, and the study of Al-Qurashi (2011) illustrated the existence of negative correlation between the future anxiety and the achievement motivation. Other studies explained the existence of negative correlation between the future anxiety and self-efficiency like Wadah (2019).

According to the variable of psychological happiness, there are many studies such as Al-Jammal (2013) and (Khailah and Martakoush, 2019) whose results showed that there are differences in the level of psychological happiness of their sample individual from moderate to high level according to the different circumstances and crises that those study populations face. Furthermore, there are some studies that tackled the variable of happiness with other variables such as Peterson, et al. (2007) whose results illustrated the existence of strong correlation between the personality forces in its dimensions (Love, hope, love of reconnaissance, and vitality) with a trend towards happiness and professional satisfaction.

With regard to the studies that tackled the topic of Moodle system, the studies of Elmahddi and Osman (2012), Gedera, et al. (2013), and Zengin (2012) demonstrate that the (Moodle) system is one of the motivating systems for both academic staff and students to use the internet network in the educational process.

Besides, these studies' findings explained that Moodle system provides self-learning environment and enables the student to interact positively with the educational material. In addition, Mahmoud (2015) showed the effectiveness of using Moodle in education and its positive influence on the achievement and skill aspect and increasing the level of the achievement motivation.

The current study stands out from others because it deals with two important variables at once: future anxiety and psychological happiness, where thinking about the future is considered an important factor in anxiety arousal in general as well as in addition to the low level of psychological happiness, particularly when individuals seek to achieve their goals and meet their requirements in light of contemporary life.

The most concerning aspect for university students is their planning for the future, assuring professional achievement, self-realization, and the development of social relationships. His future ambitions and ambitions, as 
well as his failure to effectively plan for life situations, have resulted in negative reactions that may obstruct him from achieving his goals.

\subsection{The present study}

The COVID-19 pandemic has introduced an additional layer of complexity because most countries around the world cannot predict what will happen in the future as a result of the rapid spread of this virus. and the inability to control it. This just tended to muddle matters further when it comes to increased worry about what will happen among university students and those who wish to fulfill their graduation requirements in order to enter the workforce and achieve their aspirations.

As a result of the individual's misperception of future events and distrust in his ability to deal with them, anxiety can turn into a horror source. Because of this, the individual may view these events negatively due to connections between the past, present, and future, resulting in an inability to adapt to events that meet his future. University students are the building blocks of tomorrow's society, and they go through a crucial developmental phase during their university years, becoming well-prepared to take on a variety of jobs in the future. The current study is being undertaken under unusual circumstances in order to examine and explore the impact of employing Moodle in teaching university courses on future anxiety and psychological happiness among students at Al-Salt College for Humanities. Thus, the following research hypotheses were investigated in this study:

1. There are no statistically significant differences at the level of significance $\alpha \leq 0.05$ at the level of future anxiety among experimental group individuals in the two applications (pre-application and postapplication) because of using Moodle in teaching the university courses.

2. There are no statistically significant differences at the level of significance $\alpha \leq 0.05$ for the level of psychological happiness among the experimental group individuals in the two applications (pre-application and post-application) as a result of using Moodle in teaching the university courses.

\subsection{Aims of the study}

The unpredictability of the coronavirus epidemic presented asignificant challenge to educational systems in many countries around the world, and led to the closure of a number of educational institutions to prevent infection among students. Happiness is seen as a central axis in positive psychology, with numerous studies that aim to find ways to achieve.. Since happiness is associated with future anxiety, everybody attempts to obtain a positive mood state of the individual, satisfaction with life and its quality, self-esteem, and optimism as the greater aim of life. The degree to which a person experiences psychological happiness is determined by his degree of anxiety, psychological state, and social relationships. Therefore, the current study aims to determine the impact of employing Moodle in teaching university courses on future anxiety and psychological happiness among university students under the circumstances of the coronavirus crisis.

\subsection{Limitations}

One of the limitations of the study is the small number of participants, and the fact that the study was applied to different academic disciplines in one university college. It was applied to one E-learning management systemMoodle. Therefore, the researchers had to use nonparametric tests to ensure the validity of the results. The results can be generalized to samples similar to the present study sample.

\section{Method}

The researchers have used the quasi-experimental approach of single experimental group design in order to know the independent variable (E-learning management system) on the two dependent variables (future anxiety and psychological happiness) through comparing the pre-test results at the beginning of the summer semester with post-test results after the end of the semester.

\subsection{Participants}

The study population consisted of 1,002 Al-Salt College of Humanities students (males and females) during the summer semester of 2019/2020. In this, a class-style sample of 75 students were chosen from various disciplines, 
and all academic staff in the college that used the Moodle system in teaching various university courses Table 1. The application of the two study tools was approved by the college deanship.

Table 1: Demographic characteristics of the participants $(N=75)$

\begin{tabular}{ccccccc}
\hline Specialization & Sex & \multicolumn{2}{c}{ Educational level } & \multicolumn{2}{c}{ Total } \\
& & First & Second & Third & Fourth \\
\hline Libraries and information management & Males & - & - & - & - & - \\
English language and its literatures & Females & - & - & 1 & - & 1 \\
& Males & - & 2 & 3 & 3 & 8 \\
Arabic language and its literatures & Females & - & 1 & 2 & 2 & 5 \\
& Males & 4 & 3 & 5 & 8 & 20 \\
Child rearing & Females & 1 & 1 & 1 & 3 & 6 \\
& Males & 3 & 3 & 8 & 9 & 23 \\
Total & Females & - & 2 & 4 & 6 & 12 \\
\hline
\end{tabular}

\subsection{Study tools:}

\subsubsection{Future Anxiety Scale (FAS)}

After reviewing previous theoretical literature such as studies by Al-Tukhais (2014), Mo'ayad (2010), and AlMashyakhi (2009), the two researchers developed a scale for future anxiety that consists of 30 paragraphs, each with its own weight listed in a triple gradient ladder (always apply, sometimes apply, rarely apply). A group of experienced educators reviewed the scale to confirm its validity, and the necessary amendments were made based on their feedback. The scale's construction validity was also confirmed by calculating the correlation coefficient between each paragraph and the overall degree of the scale, with the coefficient ranging from 0.52 to 0.81 , with all of them being statistic.

\subsubsection{Psychological Happiness Scale (PHS)}

The researchers used the psychological happiness scale developed by Abbott, et al. (2006) and localized by AlJammal (2013). This scale was developed by the two researchers in the Jordanian environment. Furthermore, the scale is made up of 42 paragraphs, each with its own weight listed in a pent-up (five-way) gradient ladder (strongly agree, agree, neutral, disagree, strongly disagree);to confirm the scale's construction validity, the correlation coefficient was calculated between each paragraph and the total degree of the scale, with coefficients ranging from 0.46 to 0.77 .

Table 2: Reliability coefficients of PHS dimensions and total score

\begin{tabular}{cccc}
\hline Dimensions & Paragraphs number & Test Retest & Internal consistency \\
\hline Self-independence & 7 & 0.67 & 0.75 \\
Environmental empowerment & 7 & 0.70 & 0.73 \\
Personal development & 7 & 0.69 & 0.72 \\
Positive relations with others & 7 & 0.71 & 0.79 \\
Meaningful life & 7 & 0.68 & 0.73 \\
Self-acceptance & 7 & 0.76 & 0.84 \\
Total degree & 42 & 0.78 & 0.82 \\
\hline
\end{tabular}

\subsection{Statistical analysis}

Data analysis was performed using the statistical package of social science (SPSS) version 26.0 to check the efficiency of using Moodle in education. The Wilkokson test with $Z$ indication was used to reveal the mean differences between the two means of the two sample grade rankings that are related and connected to the students' responses on the future anxiety scale in the pre- and post-application. To assess the efficacy of using Moodle in education, the researchers used the Wilkokson test with Z indication to reveal differences in the means of the two samples' grade ranks, which are related to the students' responses on the scale of psychological happiness in the pre- and post-application. 


\section{Results}

First Hypothesis: There are no statistically significant differences at the level of significance of $\alpha \leq 0.05$ at the level of future anxiety among experimental group individuals in the two applications (pre-application and postapplication) because of using Moodle in teaching the university courses.

From the findings mentioned in Table 3 , it has been noticed that the value of $Z$ to use the E-learning management system in teaching the university courses on the tool as a whole was -7.53 in which its significance level was 0.000 that represents statistical significance at $\alpha=0.05$; this indicates that there are statistically significant differences in the level of the future anxiety for the study group individuals in the pre-scale and post-scale, in favor of the postscale, which means low future anxiety level after using Moodle in education. This illustrates the positive influence of using Moodle in teaching the university courses.

Table 3: Wilkokson test: Pre-application and post-application on FAS

\begin{tabular}{cccccccc}
\hline Scale & Sample Type & Number & Mean & Std & $\begin{array}{c}\text { Difference between } \\
\text { Means }\end{array}$ & Z & Sig. \\
\hline Future anxiety & Pre & 75 & 3.45 & 0.81 & 1.37 & -7.53 & $* 0.000$ \\
& Post & 75 & 2.08 & 0.26 & & & \\
\hline
\end{tabular}

Second Hypothesis: There are no statistically significant differences at the level of significance of $\alpha \leq 0.05$ of psychological happiness among the experimental group individuals in the two applications (pre-application and post-application) because of using Moodle in teaching the university courses.

The results mentioned in Table 4 showed that the value of $Z$ for the six psychological happiness dimensions were ranged from -6.27 to -7.56 and the significance level was 0.000 , which indicates that there are statistically significant differences at $\alpha=0.05$ among the levels of psychological happiness for the study group individuals in the two scales: pre-scale and post-scale in favor of post-scale because of the use of E-learning management system in teaching university courses.

Table 4: Wilkokson test: Pre-application and post-application on PHS

\begin{tabular}{|c|c|c|c|c|c|c|c|}
\hline Dimensions & $\begin{array}{c}\text { Sample } \\
\text { Type }\end{array}$ & Number & Mean & Std & $\begin{array}{c}\text { Difference } \\
\text { between Means }\end{array}$ & $\mathbf{Z}$ & Sig. \\
\hline \multirow[t]{2}{*}{ Self-independence } & Pre & 75 & 2.61 & 0.65 & 0.59 & -7.55 & 0.000 \\
\hline & Post & 75 & 3.20 & 0.49 & & & \\
\hline \multirow{2}{*}{$\begin{array}{l}\text { Environmental } \\
\text { empowerment }\end{array}$} & Pre & 75 & 2.71 & 0.54 & 0.58 & -7.56 & 0.000 \\
\hline & Post & 75 & 3.29 & 0.39 & & & \\
\hline \multirow{2}{*}{$\begin{array}{c}\text { Personal } \\
\text { development }\end{array}$} & Pre & 75 & 2.54 & 0.57 & 0.53 & -7.54 & 0.000 \\
\hline & Post & 75 & 3.07 & 0.40 & & & \\
\hline \multirow{2}{*}{$\begin{array}{l}\text { Positive relations } \\
\text { with others }\end{array}$} & Pre & 75 & 3.0 & 0.86 & 0.50 & -6.39 & 0.000 \\
\hline & Post & 75 & 3.50 & 0.51 & & & \\
\hline \multirow[t]{2}{*}{ Meaningful life } & Pre & 75 & 2.53 & 0.57 & 0.53 & -7.53 & 0.000 \\
\hline & Post & 75 & 3.06 & 0.36 & & & \\
\hline \multirow[t]{2}{*}{ Self-acceptance } & Pre & 75 & 2.93 & 0.91 & 0.51 & -6.27 & 0.000 \\
\hline & Post & 75 & 3.44 & 0.55 & & & \\
\hline \multirow[t]{2}{*}{ Total degree } & Pre & 75 & 2.72 & 0.20 & 0.54 & -7.53 & 0.000 \\
\hline & Post & 75 & 3.26 & 0.14 & & & \\
\hline
\end{tabular}

Furthermore, the findings revealed that the $Z$ value of using an E-learning management system to teach university courses on the whole was -7.53 , with a significance level of 0.000 and statistical significance of 0.05 ; this indicated that there are statistically significant differences in the level of psychological happiness for the study group individuals in favor of post-scale. As a result, the pupils experienced a high level of psychological happiness. 


\section{Discussion}

The findings revealed that utilizing an E-learning management system (Moodle) in university courses has helped students feel less anxious about the future. The pre-anxiety level was high at the start of the epidemic, which resulted in university closures, causing significant anxiety among students about their education and careers as well as their futures; the inability among all other members of society to predict future circumstances also added to the students' anxiety levels. Following that, universities took the required steps to continue the educational process via electronic education. Al-Balqa Applied University was one of these universities, and it was the first to use Moodle to teach university courses. The two researchers attribute the low future anxiety levels in the postscale to the features of the Moodle system, such as the ability to connect with the teacher in real time, asynchronously tracking learning by connecting educational material and storing it on the system in addition to having access to the required educational activities, as well as the provision of a chat room and other characteristics that the system provides, which leads to student reassurance and stability. We believe that the reasons stated above led to the students' low anxiety levels over their university future, as they began to feel as if they were in the classrooms where their courses and tests were conducted on a regular basis. The two researchers noted that feeling addressed the causes of anxiety in students and reducing them reflected in the study's findings. Some study results, such as those of Mahmoud (2015) and Ibrahim (2017), have shown the efficiency of E-learning management systems in education and in increasing the cognitive attainment and motivation for achievement.

Furthermore, the findings of these studies revealed that the diversity of content provided by Moodle accompanied by appropriate use of images, animations, music, voice, video and educational material; all of which led to added motivation for students; it also encouraged staff to depend on themselves and enhanced the abilities of the students who do not usually participate in discussion and debate in the traditional classroom. The current findings are consistent with those of Ibrahim (2017), who found that utilizing Moodle in education increases positive flexibility for students by allowing them to own their learning. Positive flexibility is defined as having appropriate solutions to difficulties, which leads to increased capacity and skills in problem-solving, embracing bad feelings and working to overcome them, and solving problems and pressures as challenges to be addressed and overcome. The results of Bahmad and Totai (2018) indicated that $69 \%$ of the study sample had medium levels of future anxiety and the two researchers considered it as motivation anxiety, which is important to push individuals to excel.

The findings have illustrated that using an E-learning management system in teaching university courses has contributed to increasing the level of psychological happiness wherein the pre-level of psychological happiness was low at the beginning of the coronavirus epidemic because of the extraordinary circumstances that the world was experiencing in general, since no one can predict what will happen tomorrow, as the spread of the virus was rapid, and all had started to seek suitable ways and solutions to reduce the impacts of this pandemic in all areas of life; this is what led universities to resort to electronic education. For instance, Al-Salt College of Humanities like the rest colleges of Al-Balqa Applied University resorted to using the E-learning management system (Moodle) in teaching the university courses and completion of the first hypothesis finding which revealed the low level of the future anxiety for the students, which led to a high level of psychological happiness because of there assurance they received for their educational and professional futures. So, the level of their psychological happiness was increasing.

Furthermore, the education and learning center following-up the students and academic staff, provision of free internet bundles for the students, and the decision of the Council of High Education to provide the opportunity for students to convert their final marks to Pass/Fail led to a rise in students' psychological morale and motivation for educational attainment (Ministry of Higher Education and Scientific Research, 2020). All of this contributed to increasing the students' ability to face psychology pressure and consequently, a higher level of their psychological happiness. The current study results are consistent with the findings of the studies of Al-Jammal (2013) and (Khailah and Martkoush, 2019), where the findings revealed the existence of differences in the level of psychological happiness for the students from medium to high according to the various circumstances and crises that societies witness, such as wars, disasters, and epidemics. 


\section{Conclusion}

The results showed that using an E-learning management system (Moodle in this case) in teaching university courses has contributed to reducing the level of future anxiety for the students. The level of psychological happiness was low at the beginning of the coronavirus pandemic; this is because the world was experiencing an unprecedented situation where in the future was uncertain due to the extremely rapid spread of the virus. The findings illustrated that using an E-learning management system in teaching university courses has contributed to increasing the level of psychological happiness. Future studies should encourage students to take advantage of the positive influence of using E-learning management system (Moodle) in self-learning. The authors recommend that institutions of higher education consider distance learning as a part of the educational process by allocating a part of the university courses and teaching them by using Moodle. Holding the necessary training courses to develop the academic staff skills in designing the E-learning environment as well as to train students on how to deal with electronic courses prepared through the E-learning management system is important.

\section{Acknowledgements}

The authors thank the deanship of scientific research at Al-Balqa Applied University and the deanship of Al-Salt College for Social Sciences.

\section{References}

Abbott, R., Ploubidis, G., Huppert, F., Kuh, D., Wadsworth, M. and Croudase, T., 2006. Psychometric evaluation and predictive validity of Ryff's psychological well-being items in a UK birth cohort sample of women. Health and Quality of Life Outcomes, 4(76), https://doi.org/10.1186/1477-7525-4-76.

Al-Jammal, S., 2013. Psychological happiness and its relation with educational attainment and direction towards university study for students of Tabouk university. Educational and Psychological Studies,28(78), pp.1-65.

Al-Mashyakhi, G., 2009. Future anxiety and its relation with both of self efficiency and ambition level. Unpublished Ph.D. dissertation, Um Al Qura University, KSA.

Al-Momani, M.and Naeem, M. 2013. Future anxiety for the students of community colleges in Galilee region in light of some variables. Jordanian Journal of Educational Sciences, 9(2), pp.173-185.

Al-Qurashi, M.and Abed, B., 2011. Motive for achievement and its relation with future anxiety for a sample of Um Al-Qura university students. Unpublished Master's thesis, Um Al Qura University, KSA.

Al-Sabawi, F., 2007. Future anxiety for the students of education faculty and its relation with sex and specialization. Unpublished Master's thesis, Al-Mosul University, Iraq.

Al-Safasfeh, M.and Al-Mahameed, S., 2007. Professional future anxiety for Jordanian universities students and its relation with some variables. Journal of Psychological and Educational Sciences,8(3), pp.126-142.

Al-Taher, T., 2010. Psychological pressures sources as recognized by university students and its relation with future anxiety on a sample of Ghouta students. Journal of Humanities and Social Sciences, 1, pp.262-285.

Al-Tukhais, I. 2014. The effectiveness of a realistic mentoring program in reducing the future anxiety for the secondary stage students. Unpublished Master's thesis, Jing Abdul-Aziz University, KSA.

Bahmad, J. and Totay, M., 2018. Future anxiety for distance education students teachers in the two centers of Tesi waso and Bejayah. Journal of Educational and Psychological Sciences, 7(2), pp. 393-406.

Balkelani, I., 2008. Self-esteem and its relation with the future anxiety for the Arab resident community in Oslo city in Norway. Unpublished Master's thesis, Open Arab Academy, Denmark.

Barlow, D., 2000. Unraveling the mysteries of anxiety and its disorders from the perspective of emotion theory. American Psychologist,55(11), pp.1247-1263. https://doi.org/10.1037/0003-066X.55.11.1247.

Cavus, N. and Momani, A., 2009. Computer aided evaluation of learning management system. Procedia Social and Behavioral Science, 1(1), pp.426-430. http://dx.doi.org/10.1016/j.sbspro.2009.01.076

Elmahddi, I., and Osman, I., 2012. Perceptions towards computer supported collaborative learning: A case study of Sudanese undergraduate students. International Conference on E-Learning and E-Technologies in Education (ICEEE), Lodz, 2012, pp. 158-161, https://doi: 10.1109/ICeLeTE.2012.6333410.

Eysenck, M.. Susanna, P.and Santos, R., 2006. Anxiety and depression: Past, present, and future events. Cognition and Emotion, 20(2), pp.274-294. https://doi.org/10.1080/02699930500220066

Gedera, D.. Williams, J.. and Wright, N., 2013. An analysis of Moodle in facilitating asynchronous activities in a fully online university course. International Journal of Science and Applied Information Technology (IJSAIT), 2(2), pp.6-10.

Ibrahim, S. 2017. Effeciency of E-course with (Moodle) system in methods to teach philosophical subjects in developing positive flexibility and cognitive attainment and the direction towards it for the student teacher in the faculty of education. Journal of the Educational Society for Social Studies, 91, pp.145-186. 
Khailah, R.and Martkoush, S. 2019. The level of psychological happiness for the academic staff field study in Tishreen university. Journal of Tishreen University for Research and Scientific Studies: Arts and Humanities,41(3), pp.131-147.

Mahmoud, A., 2015. The effectiveness of a proposed program in using the E-learning management system (Moodle) in education and its influence on the skill and attainment for the commercial education students in education FacultySohag. Educational Journal, 40, pp.51-90.

Miller, D.. Nickerson, A.. Chafouleas, S. and Osborne, K. 2008. Authentically happy school psychologists: Applications of positive psychology for enhancing professional satisfaction and fulfillment. Psychology in the School, 45(8), pp.679-692. https://doi.org/10.1002/pits.20334

Ministry of Higher Education and Scientific Research., 2020. Applying the principle of successful and failing to distance teaching courses. [online] Available at: https://www.addustour.com/articles/1168419 [Accessed 10 August 2020].

Mo'ayad, H., 2010. Future anxiety for youth and its relation with some variables. Journal of Educational and Psychological Researches, 7(27), pp.321-377.

Molin, R., 1990. Future anxiety: Clinical issues of children in the latter phases of foster care. Child and Adolescent Social Work Journal, 7(6), pp.501-512.

Murad, O., 2021. Effectiveness of a cognitive-behavioral therapy program on reducing psychological stress and improving achievement motivation among university students. Universal Journal of Educational Research, 9(6), pp.1316-1322. https://doi: 10.13189/ujer.2021.090621

Murad, O., 2020. Social anxiety in relation to self-esteem among university students inJordan. International Education Studies, 13(2), pp.96-103. https://doi:10.5539/ies.v13n2p96.

Peterson, C.. Ruch, W.. Beerman, U.. Park, N. and Seligman, M., 2007. Strengths of character, orientations to happiness, and life satisfaction. The Journal of Positive Psychological, 2(3), pp.149-156. https://doi.org/10.1080/17439760701228938

Sa'di, R.and Shraeebeh, B. 2017. Future anxiety and its relation to psychological pressures for a sample of Tishreen university students. Tishreen University Journal for Research and Scientific Studies: Arts and Humanities, 39(4), pp.15-28.

Spence, S. H. and Rapee, R. M., 2016. The etiology of social anxiety disorder: An evidence-based model.Behavior Research and Therapy,86, pp.50-67. https://doi.org/10.1016/j.brat.2016.06.007

Suleiman, S., 2010. Happiness and satisfaction are precious wish and a classy industry. World of Books for Publishing, Cairo.

Wadah, F., 2019. Future anxiety and its relation with self-efficiency for a sample of Al-Wadi university students. Journal of Educational and Psychological Sciences, 5(4), pp.69-90.

Zayed, H., 2020. Distance learning in facing new corona. . [online] Available at: https://www.scientificamerican.com/arabic/articles/news/distance-learningversus/covid19 [Accessed 25 August 2020].

Zeidan, S., 2007. Youth's concerns about the future-field study on the students of education faculty. Damascus University. Publications of Damascus University, Syria.

Zengin, Ö., 2012. A case study on Moodle: Investigating students' perceptions on the use of Moodle. 2-4 April 2012, Dublin, Ireland \& UK Moodlemoot 2012 Conference Publication ,pp. 28. 